\title{
The End of a Custom: A Social Necessity or a Lust for "Modernisation"? The Case of Sergiani in Megala Kalyvia (Trikala, Greece)
}

\section{Konstantinos Dimopoulos}

Ph.D. student, School of Physical Education and Sport Science, National and Kapodistrian University of Athens

\section{Vasiliki Tyrovola}

Emeritus Professor, School of Physical Education and Sport Science, National and Kapodistrian University of Athens

Maria Koutsouba

Associate Professor, School of Physical Education and Sport Science, National and Kapodistrian University of Athens

Doi: $10.1515 / \mathrm{mjss}-2017-0042$

\begin{abstract}
The custom as an act inherently includes the concept of compulsory repetition and expresses the community as a whole. Through custom and ritual, every local or wider community discovers its own identity, but also the ritual is the vehicle through which the inhabitants of the local community give shape to that identity and are influenced by it. The custom of sergiani was a cultural act performed by the inhabitants of the Megala Kalyvia municipality, as the latter forms part of the wider Karagkounides group. The aim of this paper is to shed light on the custom of sergiani performed in Megala Kalyvia (Trikala, Greece), as well as to emphasise on the reasons why the custom stopped being performed. The collection and processing of data is based on the principles of ethnographic study. The new socioeconomic, historical and cultural facts that prevailed let to the discontinuance of the custom and the accompanying dances, as it occurred with other cultural and dance practices, and it was sealed by the historical structure a dependent - in a broader sense - local social and cultural identity. The president of the municipality, as an expression of the occidental perception with foreign cultural influences contrary to the perceptions of its inhabitants, contributed, with his actions, to the alienation of the local cultural identity.
\end{abstract}

Keywords: Greece, dance, sergiani custom, social practices, social structures.

\section{Introduction}

The custom as an act inherently includes the concept of compulsory repetition and expresses the community as a whole. Although custom, rite and ritual are interconnected vessels, however, the custom itself does not present as much religious depth as the ritual (Puchner, 2009:199). Nevertheless, the structures and the functions of the custom and the ritual are fluid, as the custom can also present a religious character, just exactly as the ritual. Besides, according to Geertz ([1973]2003) religion is present in cultural performances (Geertz, ([1973]2003:119), in such a way that the custom as a cultural act includes the element of religiousness and, hence, of the ritual. Through custom and ritual, every local or wider community discovers its own identity (cultural, 
ideological, political, religious, gender-related, and so on), but also the ritual is the vehicle through which the inhabitants of the local community give shape to that identity and are influenced by it (Mendoza, 2000).

The custom of sergiani is an example of those customs. It was performed exclusively within all lowland communities in the valley of Thessaly, composed exclusively of the Karagkounides ethnic group. The custom of sergiani was a cultural act performed by the inhabitants of the Megala Kalyvia municipality, as the latter forms part of the wider Karagkounides group.

The aim of this paper is to shed light on the custom of sergiani performed in Megala Kalyvia (Trikala), as well as to emphasise on the reasons why the custom stopped being performed. More specifically, we shall use the concepts of the "modernisation" and "innovativeness" as analytical tools in order to bring out the reasons that led to the abolition of the custom by the middle of the 1960s, as well as to investigate - through the abolition of the custom - the terms and conditions under which the local cultural identity was reshaped and redefined.

\section{Methodology}

The collection and processing of data is based on the principles of ethnographic study and derives from primary and secondary sources (Buckland, 1999; Giurchescu, 1999; Crang, \&Cook, 2007; Robson, ([1993]2007); Sklar, 1991, Gkefou-Madianou 1999; Lydaki, 2001). Primary sources refer to the data coming from in-situ research, through interviews (open-type questions for semi-structured interview and unstructured interview), and the participant observation combined with simultaneous audio and video recording of the inhabitants of the community. Secondary sources refer to the review and use of the existing literature and was based on the principles of archival ethnography (Gkefou-Madianou, 1999) and historical research (Adshead \& Layton ([1983]1988). The Geertz model of the "thick description" ([1973]2003) was used for the collection, presentation and analysis of the data, whereas the methodological model of Tsoukalas (1983) served as a tool for data processing and interpretation, who uses the analytical tools of innovativeness and modernism, while considering that the collective procedures are a product of a central interference, exactly as David would claim in 2014, who uses the consolidated term of globalisation in the modern world which influences all cultural aspects of a society. Finally, the Geertz model ([1973]2003) was also used, according to which cultural performances are also religious performances.

\section{Data Analysis}

\subsection{Megala Kalyvia (Trikala): the place and the people}

The village of Megala Kalyvia lies in the lowland region of Trikala, Greece, and precisely, in the southwest part of the region. It used to be the administrative centre of the community named after the village under Kapodistrias Reform Law ${ }^{1}$ (together with the communities of Glinos and Agia Kyriaki), whereas it now belongs to the municipality of Trikala city. It is $8 \mathrm{~km}$ away from the city of Trikala and it is the last community before reaching the province of Karditsa. With a population of 1.849 inhabitants (according to the census of 2011) it occupies an area of 2.900 hectares and has an altitude of 105 metres. The community of Megala Kalyvia, is therefore, the frontier village between the provinces of Trikala and Karditsa, as it can be seen below.

\footnotetext{
${ }^{1}$ Kapodistrias reform is the common name of law 2539 of Greece, which reorganised the country's administrative divisions. 


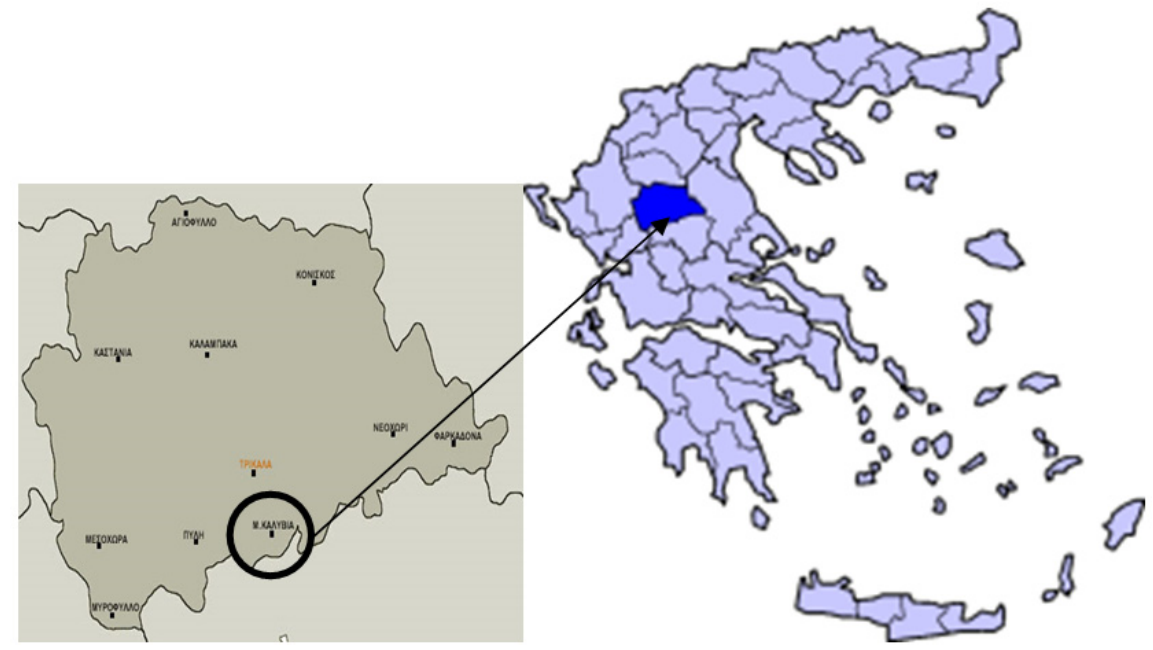

Map: Megala Kalyvia and its geographic position

Sources: https://www.google.gr/search?q...

Its initial name was Kalyvia. In the beginning of the 19th century, there used to be several settlements, such as Paschaliori, Kavoures, Logarakos, Kyrazoi, Marmaras and Kalyvia (Chiotis, 1997:13). This can also be proved by the script number (protesi) ${ }^{2} 39$ of the monastery of Dousiko (16th-17th century). Moreover, the settlement of Paschaliori is dated back to 1592 (Ntoulas, 2011: 472). The definition "Megala" (Great) appears to have been introduced at a later stage, when all above settlements were unified, apparently around 1810. The name "Kalyvia" is documented for the last time in 1838. According to earlier oral narrations of two locals, F.Papanikolaou (1881-1967) and P. Karalis (1892-1967), "...Mpeis, the representative of Ali Pasha of Ioannina, asked the Kotsampasis ${ }^{3}$ (local Christian notable) how they could create a big village such as Megalos Palamas in Karditsa. The Kostsampasis replied that that would be possible by unifying all above settlements..." (Chiotis, 1997:21). Hence, around 1810 all settlements were unified and the community was renamed to Megala Kalyvia.

The inhabitants of Megala Kalyvia belong to the ethnic group of Karagkounides and they are really proud of their identity. Their main activity is mostly agriculture, while animal husbandry is mainly used to satisfy family needs. Mixing with other populations was rather scarce. The "foreign" elements appear to arrive mostly after 1900, and they came mainly for Karagkounides communities. The ethnic group of Vlachs also settled in the community: they would stay there during the winter months and they would leave in summer (Chiotis, 2005: 240). They mainly came from the Vlach communities of Gardiki or Moutsiara, and their arrival is dated around 1900. Their main activities were animal husbandry, trade and dressmaking. No agricultural holding was conceded to them, they only received a parcel and 0,5 hectares of arable land (Chiotis, 1997: 66). It is worth mentioning that the Vlach population abandoned the community and moved either to the nearby town of Trikala or to Athens (Chiotis, 2005: 240).

\subsection{The custom of sergiani in Megala Kalyvia}

The custom of sergiani was performed within the municipality of Megala Kalyvia, but also in other municipalities belonging to the Karagkounides ethnic group. It was divided in two periods: the first

\footnotetext{
${ }^{2}$ Monastery script, in which pilgrims-donors are listed.

${ }^{3}$ Kotsampasis: it comes from the Turkish word kocabașı (koca = great, big, old + baș $=$ head, first). They were the local Cristian notables, on a province level, during Ottoman period.
} 
period would start on Epiphany Day and end on Carnival Sunday, whereas the second one lasted from the first day of Easter (Easter Sunday) until the third day of Easter (Easter Tuesday). In previous periods, only women participated in the custom performance, while men would just watch or sit at the nearby cafes. During the Carnival period, women danced every Sunday morning after mass on the church courtyard. They would also dance during the evening on the village square or any other specific place especially adjusted for this purpose. Moreover, women could gather any other day expect Sunday and perform the sergiani custom, in a more closed, informal way of performance, taking place in the neighbourhoods, hence, in more closed spaces.

The sergiani was an exclusively female business. However, women's freedom to perform was limited by the ritual character of the custom, in a way that they would follow a strict order and position within the dance performance. The position of each woman within the dance circle depended on their social status, in combination with their biological age. This meant that the elderly woman would have a front position within the circle, as they were the ones with a more important social position. They were followed by the married women, but not in any random order: their social age, meaning, their marriage age was the determinant factor for their position. If, for instance, a woman was 25 years old but was only married for a year, she would be placed after a 23-year old woman that was already married for 3 years. That was the general rule; however, if some women were friends, then there was a - rather rare - chance that they would dance one next to each other, if there was an insignificant social and biological age difference. The end of the dance circle was composed of the engaged women that were initiated into the dance and song performance with the help of the elderly women.

Both in Carnival and Easter sergiani, dances and songs performed did not have a random character and there was no room for personal dance preferences. The songs, as well as their order, was strict and predefined, the repertoire was specific and the songs were based on antiphony. The first ones to sing were the elderly women, and they were repeated by the younger ones. There were no musical instruments and the female voices was the only accompaniment to the dance, as it occurred in the cases of other communities composed of the Karagkounides ethno-local group (Dimopoulos, et.al. 2009; Dimopoulos, et.al. 2010; Dimopoulos 2011). Moreover, dances was also very a predetermined element and they presented no great variety. There was just one or two movement motifs that were constantly repeated and they would stress the ritual character of the custom. Movements were slow, walking-paced and there was no room for showing off or dance figures. The only difference between the Carnival and the Easter sergiani was the content of the songs. Whereas the Carnival sergiani songs has a more lugubrious character, the Easter sergiani had a more festive content. The table below summarises the similarities and differences between the two periods of sergiani.

Table 1: Similarities and differences between Carnival sergiani and Easter sergiani

\begin{tabular}{|l|l|l|}
\hline Custom & Carnival sergiani & Easter sergiani \\
\hline Time of performance & Morning and afternoon & Morning and afternoon \\
\hline Dance & Slow, solemn, ritual & Slow, solemn, ritual \\
\hline Song & Mournful content & Easter content, festive and different type of execution \\
\hline Gender structures & Exclusive female participation & Exclusive female participation \\
\hline
\end{tabular}

\subsection{The end of a custom: social or imperative need?}

The custom of sergiani stopped being performed many years ago; but what were the reasons that "forced" a whole society to abstain from performing a ritual? The answer is given by the combination of oral sources by our informants and the secondary and historical sources. Finding the answer was not an easy procedure, as nobody was willing to express himself/herself openly and unbiasedly regarding the reason why that specific custom stopped being performed. Obviously, this is due to the fact that Megala Kalyvia is a rather closed society and it has very strict structures, and therefore, the inhabitants were hesitating to speak up.

We should better take things from the start. Historically, the custom of sergiani in the 
municipality of Megala Kalyvia stopped being performed in the 60s, and specifically, in 1966 . When referring to the discontinuance of the performance, this means that women no longer danced or sang. For several years later women continued gathering without singing or dancing. At first glance, and after the initial conversation with mostly women (as they were the participants of the sergiani), but also with men, I assumed that the sergiani custom did no longer have its original meaning and purpose, as one of its purposes was the "bride-picking" functionality. Through the process of sergiani, single women had the chance to get out to the public space, which allowed matchmaking between families and marriage arrangements.

Therefore, I assumed that the custom no longer had its original function or meaning, so, women were no longer obliged to get out the public space to find someone to get married to. This would mean that it was the social need that dictated the terms for the discontinuation of the custom, as the latter no longer served any purpose of the local community of Megala Kalyvia. This has occurred in other cases likewise in the wider community inhabited by Karagkounides, in which an entire custom (Dimopoulos, et.al. 2009) or dance would stop being performed because the social society would judge them as no longer serving a need or a purpose of the community. However, my contact with the informants and the establishment of of a more personal and trustful communication with me pushed me to look from another way and get to investigate other deeper reasons that were decisive factors for the discontinuance of the custom within that specific municipality.

The constant dialogue (visits at the informants' houses every week), and followed by a grinding and constructive research, managed to shed light on the subject, and my assumptions were overturned. At this point, I have to note that I prefer not to mention the informants' names, as I have to "protect" my informants within the background of a closed community, as the one of Megala Kalyvia, especially if collected data have to do with persons and situations that arose within their community.

But let us take things from the start. Previously, it was said that the custom of sergiani in Megala Kalyvia stopped being performed in 1966. During that period, the president of the municipality was K.R. (mentioning his full name is hereby irrelevant), holding his position from July of 1964 to March of 1969 (Chiotis, 2005:205). That president carried out a great deal of infrastructure work, such as founding the local library (1965), ceding land for the construction of a nursery school (1966), the establishment of a community health centre and a veterinary clinic (1966), as well as many other infrastructure works (Chiotis, 2005: 205, 206). As it may be seen from the above, that president had a rather progressive ideology and promoted infrastructure development. He gave great attention to education (library, nursery school), but also to other sectors that would contribute to the development and progress of the municipality.

That president was the reason for the discontinuance of the sergiani custom. According to the informant A, "...sergiani was abolished by K.R., the president of the village. He wanted to leave the old things behind and cut this dance down, he wanted things to change, so that people would not dance like before. I specifically remember that [...] was dancing; he took her from the hand and told her to stop dancing. The women were dancing and he made them stop dancing. He took her by the hand and dissolved the dance circle. Since then they stopped dancing. That president wanted to abolish those customs...so he broke that order and nothing happened ever again."

The female informant B mentions that that specific "...was elected as a president and abolished the dance, he stopped it and it stopped happening. People went to the church but they would not dance neither after mass, nor later in the afternoon, sergiani was over..."

Moreover, the female informant C mentions that "...when K.R was president, the dance was abolished, as soon as he got elected [...] He was a modern politician and he used to say that the sergiani is no longer necessary...", whereas the informant $D$, when asked when the custom stopped being performed, said: "...I got married in 1964. I danced only one year, because the custom stopped in 1965-66 [...]. I think it was in 1966.

The female informant $E$ gives an interesting dimension to the subject by adding that "...he was the president of the village and his wife used to wear Karagkounides costume. When he was elected, he wanted the progress to come and he made her wear European clothes. He made her take the traditional costume off and dressed her according to the European dress code, this is how it was called back then. Gradually we all followed her example, one after another. But after the 
Karagkounides clothes were taken off completely, they would no longer go dancing with that custome and the dance stopped being performed..."

The female informant $C$ noted that "...he abolished the dance, he said that the dance is no longer needed, he cut it with a knife..." (making a horizontal sharp gesture with her palm looking backwards). Her statement is corroborated by the female informant $F$, according to whom the president used to say "... we are in Europe, he are heading towards Europe, we cannot be so far behind still as we have to be like the others, like people living in Trikala, and start wearing European clothes..."

The informant $\mathrm{G}$ mentions that "...I don't remember when it stopped but the president of the village was K.R. and he would not let them dance. He would not want it to be performed, so he abolished it. He wanted to bring modern things and change the old ones..." Finally, the male informant $\mathrm{H}$ mentions that "...those were stopped by K.R in 1966, when we has the president of the village and he believed that they were out-to-date and so he stopped them..."

From the above it is clear that secondary sources "converse" with secondary sources in absolute concordance. That president was indeed in tenure during 1966, when the sergiani custom stopped being performed in the municipality of Megala Kalyvia. His work, as shown by secondary sources, was a result of progressivism and development, which he tried to bring as the president of the municipality. The above is confirmed by the informants' statements, who describe him as a progressive, "modern" president, who did not like the "outdated" and wanted to introduce a European way of life, because he believed they are "in Europe".

Based on this political/ideological background, directly linked to the concepts of modernism and innovativeness, as well of cultural homogenisation, he started abolishing customary practices and traditional behaviours, which he believed to be retrogressive and outdated, let alone in Greece, where modernisation has always been a synonym for Europeanisation. He wanted to abolish the old customs and traditional dress code and introduce a new, European code, according to occidental standards. The truth is that he started implementing his ideas in his own house, as he encouraged his woman to take the traditional costume off and motivated her to wear new European-style clothes. He wanted to bring the winds of Europe, innovativeness, modernism and progressivism. Therefore, one day in 1966, he strictly forbade the Carnival sergiani as he ordered women to abstain from performing it, as he thought it to be old and outdated, not "modern" and it is not compatible with the new social-political and cultural conditions which were observed in the wider Greek space. He did all that without asking anyone or having into account the social impact on the community, or not even considering the needs or the desires of its members. The end of sergiani was not a social need or demand, but rather a choice of the local authority, personified by the president, that had to be respected and followed by everyone.

\subsection{The social impact and results}

The legitimate impact created after this event was the fact that the inhabitants of the municipality accepted that imposed end of the sergiani without any protest. But were they not bothered that the custom just stopped being performed following an order-prohibition of an elected president?

The answer to the above question was given with honesty and a rather sorrow tone by the informants. The male informant A stated that "...the decision of the president might have been wrong, because people back then were counting on the sergiani to spend some time outdoors and go out for a bit, escaping from their routine for 2 or 3 hours during the evening..."

The female informant $B$ mentions that the president "...was accused by the village of Megala Kalyvia, the dancing was not doing any harm. And we all commented that was wrong, the fact that he was elected as a president and abolished the dance, since we didn't understand how that dance could do any harm..."

Moreover, the female informant F comments that "...it was not well seen. They used to say that that was a chance to go out some Sundays, now we are locked in and they did not like that" [...] "...they used to talk with each other, but they would never form a complaint to anyone, as, according to them, it was the president's choice and we could do nothing about it..."

According to the above, the inhabitants of the municipality were unpleased with that decision. 
For them, rather than just a custom, the sergiani was a place of meeting and a way of entertainment. It was a chance for the community to gather, as at that time women could not go out, since coffee bars were exclusively a mens' place. Therefore, the custom gave them the opportunity to get out of the house, have some fun, sing and dance, while men could enjoy watching the performance and see their women dancing. According to the informants, the sergiani functioned as a pressure valve for women, as they used it to "escape" from the daily routine and forget about the problems and heavy household workload.

The inhabitants never understood their president's decision, as deep inside them they would never accept it, since they didn't want the custom to stop. Both genders were unpleased by that decision, because it was a custom inherently connected with their local cultural identity and didn't agree with its discontinuance. Nevertheless, despite the fact that their decision-prohibition was not embraced, it was still accepted and, according to the informants, nobody ever complained about it. Perhaps the reason for that was their obedience to the local authority or they might have also thought that their reaction would bring no outcome, or maybe they started realising that a new day was coming, in which all old and outdated elements should cease to exist. It is no accident that exactly that time the president of the village "forced" his wife to wear European-occidental clothes and no longer follow the traditional local dress code, an example followed by other women. The time of the global market and cultural homogenisation had come and dictated the prohibition of every single manifestation of local identity and expression. In the municipality of Megala Kalyvia, that was accompanied by the prohibition of sergiani by the own authority, personified by the president.

This ethnographic example shows the role and the force of the dance and dance practices within the social structure and its evolution in the municipality of Megala Kalyvia. The president of the municipality, who obviously personified the local authority, decides to forbid the performance of a custom as well as the dances that constitute the core of that specific ritual procedure. He did not do so for political or partisan purposes, as it often occurs in the case of prohibition or change in the way of performing some customs (Austerlitz, 1997; Brandes, 1990; Cowan, 1998; Daniel, 1991, 1995; Loutzaki, 1994; Manning, 1993, 1995; Mohd, 1993; Petrides, 1988; Ramsey, 1997; Reed, 1998; Strauss, 1977). The present case is rather related with reasons of progressivism and innovativeness. He considered the custom to be ancient and outdated and would no longer have place in the new emergent social situation, structured on the standards of the occidental world, modernisation and social-economic homogenisation.

It is known that customs are not a static phenomenon, but they have a rather dynamic character: they keep changing and constantly readapting within the framework of a dialectical relation that connects a given social whole to the surrounding space. Moreover, customs are not detached from the cultural net of the society, as they include cultural practices, such as dance and music. If dances stop and, consequently, customs including dances, then the cultural expressions of the community will also cease. In that specific case, the president gave an end to the ritual procedure and included dances of the sergiani custom, as he felt that the society moves forward and people enter a new era of modernisation. He abolished the custom because the inhabitants of the municipality, a regional social formation, headed towards the rationalised approach of an idealised future, where the old and the outdated had no longer a place within. In the studied case, the modernisation was projected as a rupture with the past and as an ex nihilo construction of a modern notional structure, in such a way that the cultural fabric of the municipality seemingly took the form of rupture with the past. Besides, as it occurred with all the municipalities of the Greek space, even before the founding structures of the new economic integration in the new global system become visible, the political and cultural impact of this integration had already made its appearance.

According to David (2014), there is "... a greater influence of globalization in areas such as music, fashion, religion, and politics...". Dance can be added up to the above, which is a cultural practice as well, and, what is more in that specific case, a religious/ritual practice, as it is performed during Easter period on the church courtyard. Those are fields affected by innovativeness, modernisation, or the development of global market (Tsoukalas, 1983), and later on, by globalisation (David, 2014). 


\section{Conclusions}

The research leads to the conclusion that a custom, and, subsequently, the dance procedure inherent to the custom, may stop being performed not only because of functionality reasons or other severe occurrences (war, mourning, emigration) but also because innovativeness and modernisation greatly influence cultural and customary procedures, as well as dance, music or singing practices.

The case of Megala Kalyvia is such an example, where the custom of sergiani, together with the dance and songs that accompanied it, stopped being performed, because they were no longer compatible with the new European or generally occidental way of life and they would no longer fit into the new socio-economic and cultural fabric of that period. This whole approach was expressed and imposed by the authority of the municipality, its president, who was the responsible person for the present and the future of the village. He was the one who decided to introduce the municipality of Megala Kalyvia - within the framework of modernisation and innovativeness - to the new way of living, abolishing ancient dance-musical and customary practices, such as the women-led sergiani.

It could be affirmed that the new socioeconomic conditions that prevailed upon the development of the global market on a universal level had also their impact in Greece: municipalities lost, at a great extent, their regional particularity and their cultural identity, which was influenced by the new cultural practices that prevailed in the wider occidental world, as a result of the new social and financial system, inherently linked with the evolution of the global market.

Inevitably, the prevalence of the financial production methods and the structure of a global market led to the universalisation of the historical procedures. The multidimensional structures of regional formations, not only within the wider Greek space generally, but also within the framework of the local municipality of Megala Kalyvia in concrete, in a global financial system let to the entrance of that community into a new historical path, through the introduction of a range of new institutional, ideological and cultural crystallisations. Therefore, the crystallisation of the local collective perceptions regarding the cultural identity of the municipality was a part of a different system of reference, which - contrary to the terms of preindustrial production or reproduction - was based on change and search of new ways of transcendence. Nevertheless, despite the fact that the decision of the president regarding the abolition of the custom was seen by the members of the municipality as a problem and created anxiety, because they realised the cultural impact of that abolition, however, they still accepted it as an alignment with the European or generally occidental standards. Therefore, the new local cultural identity was projected as a collective project and as a new collective vision, bringing the collapse of the traditional collective expressions. Furthermore, it is commonplace that from the moment that collective expressions and behaviours are no longer a product of a simply "internally-defined" production or reproduction, but rather become an object of a centralised or unifying interference, they degrade and fall apart (Tsoukalas, 1983).

It seems that it was an inevitable result, as the new socioeconomic, historical and cultural facts that prevailed let to the discontinuance of the custom and the accompanying dances, as it occurred with other cultural and dance practices, and it was sealed by the historical structure a dependent - in a broader sense - local social and cultural identity. The president of the municipality, as an expression of the occidental perception with foreign cultural influences contrary to the perceptions of its inhabitants, contributed, with his actions, to the alienation of the local cultural identity. He imposed a new cultural identity that was composed of the ideological and cultural elements of its institutional standards, becoming hence "evolutionary", "innovating" and "improving".

In turn, the inhabitants of the municipality, despite their apparent reactions and unpleasantness, but also influenced by the changes in the urban centres of the wider Greek space, had a passive reaction to the president's decision, perceiving it as a common purpose and progress. From one point of view, the rupture with their cultural past and their cultural identity was perceived as a rationalisation, a change of the present, as a unifying and symbolic structure, as an adaptation to the new life conditions and an integration into the "civilised world" and an adjustment to the "modern" era. From another point of view, the passiveness of the inhabitants of the municipality regarding the abolition of the custom could also be interpreted as the fear against the 
prevalent local expression of authority, the institution and the person exercising that authority, personified by the president of the municipality, especially when we are referring to 1960s Greece. Therefore, the abolition of the custom no longer had the form of divergence or conflict, but rather the form of convergence and identification which led to the shaping of new local cultural identity. Besides, it has to be reminded that the events are prepared by people, made by people, impact people and change people.

The abolition of the sergiani custom marked the readjustment and redefinition of the local cultural identity within the framework of the dialectical relation that connected the people of the community with the wider surrounding social space in Greece. It was a readjustment and a redefinition driven by the new updated social and economic structures and was based on two basic axes, either individually or in interdependence. The first axis was the people of the community under examination and formed its social background. The second axis refers to the cultural elements that composed, at that specific period, the base of differentiation or contradistinction. The need for "modernisation" expressed the position that the local society had to escape from the negative orbit in which it was moving till then. Despite the fact that it created a power conflict between people looking forwards and people fearing the future, however, the outcome of the abolition was finally perceived by the inhabitants as a natural result, since the main demand of that period was the transformation of a culturally defined social collective into a self-contained cultural and political entity based on this "modernisation".

\section{References}

Adshead, J. \& Layton, J. ([1983]1988). Dance history. A methodology for study. London: Dance Books.

Austerlitz, P. (1997). Merengue: Dominican music and Dominican identity. Philadelphia: Temple University Press.

Brandes, S. (1990). The sardana: catalan dance and catalan national identity. The Journal of American Folklore, 103(407), 24-41.

Buckland, T. (1999). [Re]Constructing meanings: the dance ethnographer as keeper of the truth. In Theresa Buckland (Ed.), Dance in the Field. Theory, Methods and Issues in Dance Ethnography (pp. 196-207). London: Macmillan Press.

Chiotis, N. (1997). Megala Kalyvia. Our place and our world. Trkala: Genesis.

Chiotis, N. (2005). Megala Kalyvia. Our place and our world. Vol. 2. Trkala: Genesis.

Crang, M., \& Cook, I. (2007). Doing ethnographies. London: Sage Publications.

Cowan, J. (1990). Dance and the body politic in northern Greece. Princeton: Princeton University Press.

Daniel, Y. (1991). Changing values in Cuban rumba, a lower class black dance appropriated by the cuban revolution. Dance Reserach Journal, 23(2), 1-10.

Daniel, Y. (1995). Rumba: Dance and social change in contemporary Cuba. Bloomington: Indiana University Press.

David, A. (2014). Embodied traditions. Guajarati (Dance) Practices of Garba and Raas in the UK context. In Linda E. Dankworth and Ann R. David (eds.) Dance ethnography and global perspectives. Identity, embodiment and culture (pp. 13-36). UK: Palgrave Macmillan.

Dimopoulos, K., Tyrovola, V. \& Koutsouba, M. (2009). The end of a ritual or the beginning of new social structures? The case of Bright Tuesday in the community of Lazarina, Karditsa, Thessaly. 23nd Congresso Mundial de Investigation de la Danza. Malaga, Spain.

Dimopoulos, K., Tyrovola, V., \& Koutsouba, M. (2010). The dance "Roimana" in the community of Krania (Kranea), Karditsa during the period 1950-1980. Gender practices and semantic components. In Proceedings of the Congress "Local Traditional Dances in Study Programs". Palamas: Karditsa.

Dimopoulos, K. (2012). Space components and gender dance practices. The lowland and mountainous communities of Karditsa Thessaly during the period 1920-1980. Athens: Master Thesis. School of Physical Education and Sport Science. National and Kapodistrian University of Athens.

Geertz, C. ([1973]2003). The Interpretation of Cultures. T. Paradellis (ed., \& transl.). Athens: Alexandria.

Gefou-Madianou, D. (1999). Culture and Ethnography. From the ethnographic realism to the cultural critique. Athens: Ellinika Gramata.

Loutzaki, I. (1994). Dance in 'Political' rhythms. In I. Loutzaki (ed.). Dance and its Socio-Political Aspects. Dance and Costume. Proceedings from the 17th Symposium of the Study Group on Ethnochoreology (pp. 6572). Nafplion: Peloponnesian Folklore Foundation \& International Council for Traditional Music.

Loutzaki, I. (2001). Folk dance in political rhythms. Yearbook for Traditional Music, 33, 127-137. 
Manning, C. (1993). Automatic acquisition of a large subcategorization dictionary from corpora. Proceedings of the 31st ACL, pp. 235-242.

Manning, C. (1993). Analyzing the verbal noun: Internal and external constraints. In Soonja Choi (ed.), Japanese/Korean Linguistics 3, Stanford, CA: Stanford Linguistics Association, pp. 236-253.

Mendoza, Z. (2000). Shaping society through dance. Chicago: The University of Chicago Press.

Mohd, A. (1993). Zapin: folk dance of the Malay world. Singapore: Oxford University Press.

Petrides, T. (1989). Greek folk dances and change. In Lisbet Torp (ed.). The Dance Event: A Complex Cultural Phenomenon, Copenhagen (pp. 151-157). In Proceedings of the $15^{\text {th }}$ Symposium of the ICTM Study Group on Ethnochoreology.

Pouchner, W. (2009). Theoretical Laography. Athens: Armos.

Ramsey, K. (1997). Vodou, nationalism and performance: the staging of folklore in mid-twentieth century Haiti. Women \& Performance: a journal of feminist theory Volume 7(2), 345-378.

Reed, S. (1998). The politics and poetics of dance. Annual Review of Anthropology. 27, 503-532.

Robson, C. ([1993]2007). Real World Research. K. Michalopoulou (ed.), V. Ntalakou, \& K. Vasilikou (trans.). Athens: Gutenberg.

Sklar, D. (1991). On dance ethnography. CORD Dance Research Journal, 23/1, pp. 6-10.

Strauss, J. (1977). The History of the People's Republic of China, 1949-1976. New York: Free Press.

Tsoukalas, K. (1983). Tradition and modernisation. Some general questions. In D.G. Tsaousis (ed.) Hellenism and hellenism. Ideological and experiential axles of the Greek society (p.37-48). Athens: Kollaros. 